$$
e=i_{a}-i_{u}-T_{u}\left(S_{a}-S_{u}\right)
$$

然料に関していえば，然料のエクセルギは，之の発

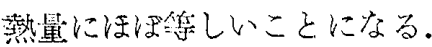

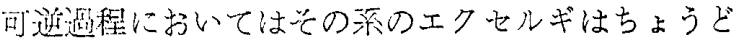

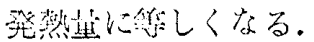

上の式で明らかなようにエクセル泣登の系自身の

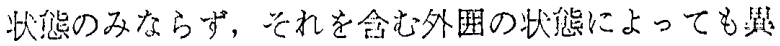
なった㑛をもつ。

[長漓昭]

\subsection{2}

※[327] エクセルギ関係の諸文献［N. Gašparović, BWK, 1961-11, Bd. 13, Nr. 11, S. 502 509, 図 4]

BWKエクセルギ特集蒝の一編として，エクセルギ 関係の諸文献を占くは1889 年 M. Gouy の文献から 現在まで総数 116 緸を選んで文献りストを作ってい る.このリストは諸研究者にとって非常に好都合なも のと考光られ、なお 116 編のうち办らきわわて最近 の(多くは 1961 年度発表の) 15 編の文献を選び, 号 の馀交内容の紹介を㧍こなっている。これらはさクセ ルギの根本概念についてのベた文献にはじまり，然袑

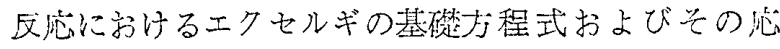

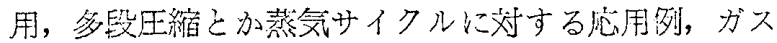
タービンに㧍けるエクセルギ平衡の問题，さらに原恶

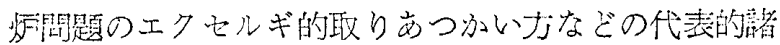
交献を列举したものであってこれらからも現在のこ の分野での傾闻苍うか肪うことができる。 またるに

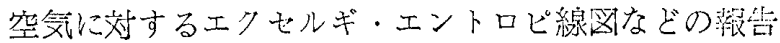

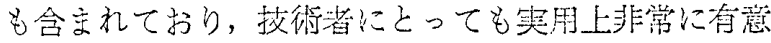
義な交献りス卜と思われる。【泿部康一]

532.529 .5

※[328]二相ほう塊流 [P. Griffith \& G.B. Wallis, Trans. ASME, Series C, 1961-8, Vol. 83, No. 3, p. 307 320, 図 12, 表 3]気水混合体の二相流り おいては，混合流，ほう塊流，摆状流などの流動椂式 が方われる。本論文は水と空気の二相ほう堖流につ

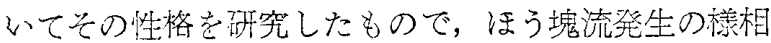
唯，定性的ではあるが，非常に詳細に記运されている。

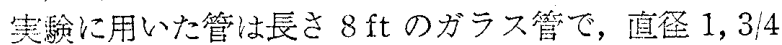
扮よび $1 / 2$ inの 3 種類について実験が行なるれてい

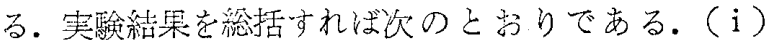
二相流を十分発達させるためには，L/D=300（ $L=$ 错 長， $D=$ 管堡）というような大きな助起区間分必瑟で

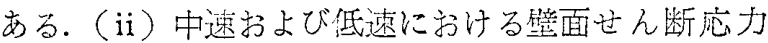

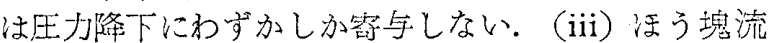

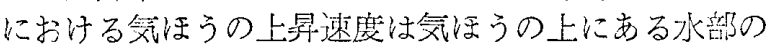

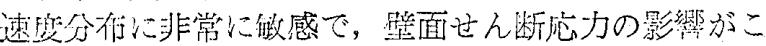
の速装分作を通してあ占方れてくる。（iv）圧力降下，

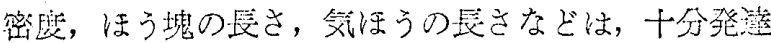
したはう塊流に対しては艮努小精造で部算することが できる。

[西川湖康]

\section{$536.24: 538.4$}

[329]対流熱交換のの静電場の影響［В.П. Мотулевич, В.М. Ерошенко, и Ю.Н. Петров, Физическая газодинамика и теплообмен, 1961, стр. 94 103, 图 4, Издательство А.Н. СССР, 68 коп] 流体の特性に更㴗与笔場の影響は以前加方研究され，

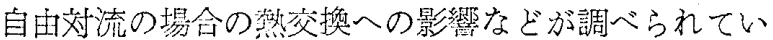

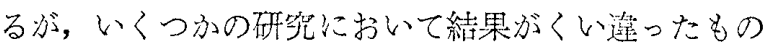

\section{となっている。}

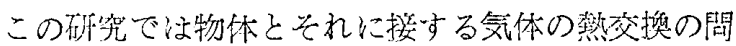

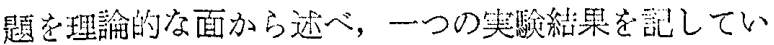
る.

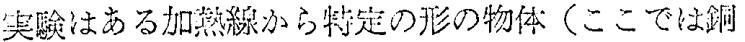
の平板と円䇴）への悲の流れが，間にある流体に電埸

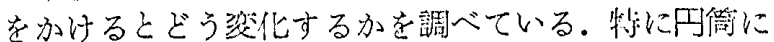

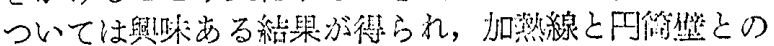

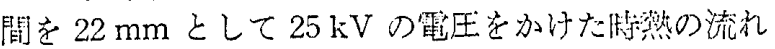

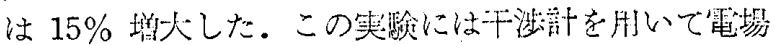

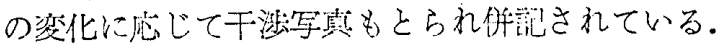

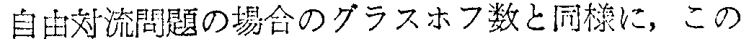
ような笔気的対流問題における特性を表わす数 $K$ と して次の式を示している。

$$
K=\frac{\Delta X \operatorname{grad} E^{2} \rho \gamma^{3}}{\mu^{2}}
$$

〔長鼻

\section{$536.242: 532.542 .2$}

[330] 二重回転円筒の間䩜方向に流れる流体の熱 伝達 〔А.И. Борисенко, Э.П. Зимин, и А.И. Яковлев, ИФЖ, 1961-10, Том. 4, №. 10, стр. 129 133】電動機の给却機構の理論的牦析がなされてい

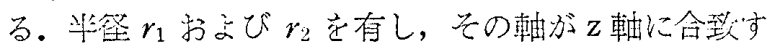
るような闹朝の回転四筒の閻を, 非圧縮性, 粘性流体 が定常的扂流をなして流れるものとし，物筫知数は一 定としてある。文ず一般的に運動方程式，エネルギ方 程式，通緮方程式をたて，流れは整効枌なものとし， 半惩方向の速度成分 $W_{r}=0$ と洘えれば，連続方程式

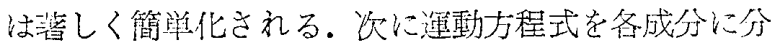
解し，連続方程王の結果を用いて積分すれば速店分伤 が得られる。この速度分布をエネルギ方积式に代入

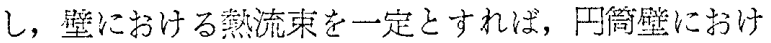
る温度こう配は 2 方向に一定となるので，容易に積分

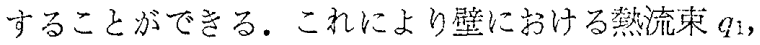
$q_{2}$ ，るいは $z$ 方向温监こう配 $A$ を与えたときの温

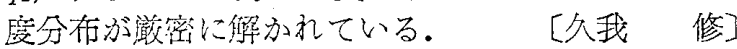

\subsection{5}

※[331] 熱源上における対流 (乱流) [H.A. Weneлев, Изв. А.Н. Механика и Машностроение, 1961 No. 4, стр. 3〜9, 図 2]埶源の上で起る対流の流 れの任意点に拝海速度 $w$ と温度 $\theta$ は次の式として 学かれる。

$$
\begin{aligned}
& w=\left\{\begin{array}{ccc}
3(1+n) & g & Q_{0} \\
4 \pi c^{2} & c_{p} \gamma_{\infty} T_{\infty} z
\end{array}\right\}^{1 / 3} \exp \left\{-\frac{1}{2}\left(\frac{r}{c z}\right)^{2}\right\} \\
& \theta=\left\{\begin{array}{c}
(1+n)^{2} \\
6 \pi^{2} c^{4} n^{3}
\end{array} \frac{T_{\infty}}{g c_{p}{ }^{2} \gamma_{\infty}^{2}} \frac{Q_{0}{ }^{2}}{z^{5}}\right\}^{1 / 3} \exp \left\{-\frac{1}{2 n}\left(\frac{r}{c z}\right)^{2}\right\}
\end{aligned}
$$

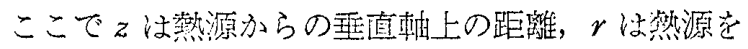
中心とする半惩の長さを売わす。

この式をもととして，熱源を通る瑟直な断面できっ た時の等温線ならびに等速度線が求められ，絬局㰥の 12 の場合の式が溥かれている。

すなわち，対流の㷁上の速底，軸上の温应上昇，空 閒中の任意の点での速废，同じく温度上景，等速線， 等温線, 流れにおける体積移動量, 刘流の平约の温淳 上昇, 流れの運動量, 流れの運動エネルギ, 熱源の発

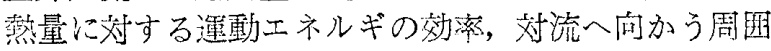

